\title{
İlkokul 4. Sınıf Öğrencilerinin Çocuk Haklarına İlişkin Algılarının Geliştirilmesi: Bir Eylem Araştırması*
}

\author{
Asli BALCI ${ }^{1}$ \\ Nurbanu ŞEREN² \\ Geliş Tarihi: 19.11.2021 \\ Kabul Tarihi: 13.12.2021 \\ Doi: $10.47503 /$ jirss.1026038 \\ Özet
}

$\mathrm{Bu}$ araştırmada ilkokul 4. sınıf öğrencilerinin çocuk haklarına yönelik algılarını oyun ve etkinlikler yoluyla iyileştirmek ve geliştirmek hedeflenmiştir. Araştırma, nitel araştırma yöntemleri içerisinde yer alan eylem araştırması desenine göre tasarlanmıştır. Araştırmanın çalışma grubunu 2020-2021 eğitim-öğretim yılında Akdeniz bölgesinde yer alan bir devlet ilkokulunda 4. sinıfta öğrenim görmekte olan 25 ilkokul öğrencisi oluşturmaktadır. Veri toplama aracı olarak zihin haritaları ve araştırmacılar tarafından hazırlanan yarı-yapılandırılmış görüşme formu kullanılmıştır. Araştırmanın başında öğrencilere zihin haritalarının ne olduğuna dair bilgi verilmiş ve örnekler gösterilmiş, daha sonra ise onlardan çocuk haklarına ilişkin bir zihin haritası oluşturmaları istenmiştir. Bu zihin haritaları incelendiğinde öğrencilerin çocuk haklarına ilişkin algılarında eksiklikler olduğu tespit edilmiştir. Bu kapsamda araştırmacılar tarafından bir eylem planı hazırlanmış ve uzman görüşü dâhilinde uygulamalar belirlenmiştir. Bu eylem planı 14 saat boyunca uygulanmıştır. Yapılan uygulama sonrasında öğrencilerden yeniden çocuk haklarına ilişkin zihin haritaları oluşturmaları istenmiştir. Elde edilen bu dokümanların yanı sıra ayrıca gönüllü beş öğrenci ile uygulamaya dair görüşmeler yapılmıştır. Veriler betimsel analiz kullanılarak analiz edilmiştir. Araştırmanın sonuçlarına bakıldığında öğrencilerin uygulama öncesinde sırasıyla en çok eğitim hakkı, oyun/eğlenme hakkı ve yaşama hakkına yönelik görüşleri olduğu; en az ise vatandaşlık hakkı, sağlık hakkı ve korunma hakkına yer verdikleri görülmüştür. Uygulama sonrasında ise öğrenciler zihin haritalarında sırasıyla en çok yaşama hakkı, korunma hakkı ve vatandaşlık hakkına değinmiştir. Uygulama öncesinde neredeyse hiç değinilmeyen korunma hakkına da uygulama sonrasında birçok çocuğun yer verdiği görülmüştür. Uygulama sonrasında tüm temalarda uygulama öncesine göre kodlara ilişkin frekansların arttığı tespit edilmiştir. Ayrıca yapılan görüşmeler sonrasında öğrencilerin uygulamaya ilişkin olumlu tutumlar geliştirdikleri söylenebilir.

Anahtar Kelimeler: Çocuk hakları, Eylem araştırması, İlkokul öğrencileri, Zihin haritaları.

\footnotetext{
* Bu makale, 12-14 Kasım tarihlerinde gerçekleştirilen 19. Uluslararası Sınıf Öğretmenliği Eğitimi Sempozyumu'nda sözlü bildiri olarak sunulmuştur.

${ }^{1}$ Yüksek Lisans Öğrencisi, Akdeniz Üniversitesi Eğitim Bilimleri Enstitüsü, Türkiye. aslbalc.07@gmail.com ORCID: https://orcid.org/0000-0002-0410-9092

${ }^{2}$ Sorumlu Yazar, Arş. Gör., Ondokuz Mayıs Üniversitesi Temel Eğitim Bölümü, Türkiye. nurbanuseren@gmail.com ORCID: https://orcid.org/0000-0002-0119-1684
}

Atıf künyesi: Balcı, A., ve Şeren, N. (2021). İlkokul 4. sınıf öğrencilerinin çocuk haklarına ilişkin algılarının geliştirilmesi: Bir eylem araştırması. Journal of Innovative Research in Social Studies, 4(2), 132146. https://doi.org/10.47503/jirss.1026038 


\section{Development of Primary School 4th Grade Students' Perceptions of Children's Rights: An Action Research}

\section{Abstract}

In this research, it was aimed to develop and improve the primary school 4th grade students' perceptions of children rights through games and activities. The research was conducted according to the action research design, which is one of the qualitative research methods. The study group of the research includes 25 primary school students studying in the 4th grade in the academic year 20202021. As a data collection tool, mind maps and semi-structured interview form prepared by the researchers were used. At the beginning of the study, the students were informed about what mind maps were. Also, some examples were introduced to the students, and then they were asked to create a mind map regarding children's rights. When these mind maps were examined, it was determined that there were deficiencies in students' perceptions of children's rights. Within this framework, an action plan was prepared by the researchers, and practices of the plan were specified within the scope of expert opinion. This action plan was implemented for 14 hours. After the implementation, the students were asked to create mind maps related to children's rights once again. Afterward, interviews were held with five volunteer students regarding the implementation. Considering the results of the study, it is observed that students mostly have opinions about the right to education, the right to play/entertainment and the right to life before implementation. After the implementation, the students mostly mentioned the right to life, the right to protection, and the right to citizenship on their mind maps. It was observed that many children included the right to protection, which was hardly mentioned before the implementation. After the implementation, it was determined that the frequencies of the codes increased in all themes compared to the pre-implementation. Besides, after the interviews, the students stated that they felt happy and excited throughout the entire implementation process.

Keywords: Action research, Children's rights, Mind maps, Primary school students. 


\section{GíRiş}

Toplumların gelişebilmesi, çocuklara verdiği önemle doğru orantılıdır. Mutlu ve refah içinde çocukluk geçiren bireyler yetişkinliklerinde iyi birer vatandaş olarak içinde bulundukları topluma da mutluluk ve ferah getirmektedirler (Akyüz, 2000). Çocukların kötü şartlarda yaşadığı, ihmal ve istismara maruz kaldığı toplumlar geri kalmış bir kültür ile nitelendirilirken; çocukların değer gördüğü, birçok alanda gelişimlerinin desteklendiği toplumlar ise gelişmiş ve gelişmekte olan bir kültür ile ilişkilendirilmektedir (Ay Zöğ, 2008). $\mathrm{Bu}$ noktada çocukların ihmal ve istismardan korunması yönünde evrensel olarak birtakım çalışmalar yapılmış ve çocuklara ait hakların varlığı kabul görerek çocuk hakları kavramı ortaya çıkmıştır. Akyüz (2000) çocuk haklarını en genel anlamda çocuğun özgürlük ve saygınlığ1 gözetilerek onun bedensel, zihinsel, sosyal, duygusal ve ahlaki açıdan sağlıklı biçimde gelişebilmesi için hukuk kuralları ile korunan yararları olarak tanımlamıştır. 20 Kasım 1989'da Birleşmiş Milletler tarafından kabul edilen ve 2 Eylül 1990 tarihinde yürürlüğe giren Çocuk Hakları Sözleşmesi, içerisinde Türkiye Cumhuriyeti'nin de bulunduğu 191 ülke tarafından onaylanarak insan haklarına ilişkin en yaygın belge olmuştur (Özdemir Uluç, 2008). Bu sözleşme, imzası bulunan taraf devletlere; çocuk veya yetişkin ayırmaksızın sözleşme maddelerinin tanıtılması ve öğretilmesi yükümlülügüüü de beraberinde getirmiştir. Bu noktada eğitimin önemi ortaya çıkmaktadır. Karaman Kepenekçi (2000) de insan haklarına ilişkin sağlıklı ve etkili bir bilinçlendirmenin yolu nitelikli bir eğitimden geçmekte olduğunu belirtmiştir. Özellikle çocukluk çağında başlayan bu eğitim, yetişkinlik döneminde demokratik bir toplum düzeninin sağlanması açısından önemli katkıda bulunacaktır. Böylece çocuklar haklarını öğrenerek kendi hayatlarına uygulayabilir, başkalarının da haklara sahip olduğunu bilerek onlara saygı duymayı öğrenebilir (Turupcu \& Gültekin Akduman, 2015). Çocuk hakları eğitimi, insan haklarının bir alt boyutu olarak çocukların en yakın çevreleri olan ailelerinden içinde bulundukları topluma kadar bir arada yaşamalarını (Washington, 2010) ve tüm bireylerdeki haklara saygı duymaları yönünde tutum ve davranış geliştirmelerini amaçlamaktadır (Covell \& Howe, 1999). Yapılan çalışmalarda hakları konusunda bilinçli olan çocukların, olmayanlara göre daha fazla sorumluluk aldıkları, empati kurdukları ve kendilerini savunabildikleri görülmüştür (Covell \& Hove, 1999; Neslitürk ve Ersoy, 2007). Nitekim Çocuk Hakları Sözleşmesi'nde imzası bulunan taraf devletlere Birleşmiş Milletler tarafından çocuk hakları eğitimi konusunda birtakım öneriler getirilmiştir. Öğretim programları içerisine çocuk haklarının dahil edilmesi de bu önerilerden biridir. Bu doğrultuda Amerika Birleşik Devletleri, Kanada, İngiltere ve İsviçre gibi birçok ülkede çocuk hakları, öğretim programları içerisine dahil edilmiştir (Ersoy, 2011).

Türkiye'de ise son yıllarda uygulanan öğretim programları çocuk merkezli olmakla beraber, çocuk haklarına da yer veren bir anlayış ile hazırlanmıştır. Çocuk hakları ile ilgili kazanım ve etkinliklerin en çok Hayat Bilgisi, Sosyal Bilgiler ve Türkçe derslerinde bulunduğu görülmektedir (Çarıkçı, 2019). Bu derslerin yanı sıra 2015-2016 eğitim-öğretim yılından itibaren ilkokul 4. sınıf programına "İnsan Hakları, Yurttaşlık ve Demokrasi” dersi dahil 
edilmiş ve çocuk hakları ile yakından ilişkili olan insan hakları, vatandaşlık ve demokrasi eğitimi gibi konular sistematik bir şekilde ayrı bir ders altında verilmeye başlanmıştır (Izgar, 2017). İlköğretimde 1,2,3. sınıf düzeylerinde Hayat Bilgisi; 4,5,6,7. Sinıf düzeylerinde Sosyal Bilgiler ve 8. Sınıf düzeyinde ise Atatürk İlkeleri ve İnkılap Tarihi derslerinde çocuk hakları ile ilgili kazanımların doğrudan yer aldığı görülürken, diğer derslerde de dolaylı yollardan kazanımların olduğu söylenebilir (Ersoy, 2008'den akt. Ersoy, 2011). 2005 yılından itibaren uygulanmakta olan ve en son 2018 yılında revize edilen Sosyal Bilgiler Öğretim Programı incelendiğinde, vizyon ve kazanımlarda çocuk haklarına yer verildiği ve kazanımların sekiz öğrenme alanı içerisinde yer edindiği görülmektedir. Bu öğrenme alanları, "Birey ve Toplum”, “Kültür ve Miras”, “İnsanlar, Yerler ve Çevreler”, “Bilim, Teknoloji ve Toplum”, “Üretim, Dağıtım ve Tüketim", “Etkin Vatandaşlık" ve "Küresel Bağlantılar" olarak yer almaktadır. Bunlar içerisinde özellikle "Etkin Vatandaşlık" öğrenme alanında bulunan kazanımların doğrudan çocuk hakları ile ilişkili olduğu görülmektedir (Milli Eğitim Bakanlığı, 2018).

Literatür incelendiğinde öğretim programlarındaki kazanımların ve ders kitaplarındaki etkinliklerin, öğrencilere etkili bir çocuk hakları eğitimini sağlama konusunda yetersiz olduğu belirtilmektedir (Durgut, 2014; Erbay, 2012; Hareket, 2015; Özdemir Doğan, 2017; Özdemir Uluç, 2008). Bu noktada öğrencilerin gelişim düzeylerine uygun çeşitli etkinliklerle çocuk hakları eğitimi gerçekleştirildiği görülmektedir (Kaymak Özmen, Öcal ve Özmen, 2011; Uçuş, 2014). Torun (2011) özellikle oyunlarla desteklenmiş bir çocuk hakları eğitiminin öğrencilerde etkili olduğunu ve kalıcılığı sağladığını vurgulamaktadır. Çocukların haklarını bilen ve bunları hayatlarına aktarabilen bireyler olarak yetişmesinde; ihtiyaçlarının belirlenmesi, ihtiyaçlar bağlamında etkinlikler hazırlanması ve etkinliklerin sonunda çocukların değerlendirilmesi önemlidir (Beeckman, 2004). Bu doğrultuda bu araştırmada, ilkokul 4. sınıf öğrencilerinin çocuk haklarına yönelik algılarını oyun ve etkinlikler yoluyla iyileştirmek ve geliştirmek amaçlanmıştır. Bu amaç doğrultusunda aşağıda verilen üç alt probleme yanıt aranmıştır.

1. Uygulama öncesi ilkokul 4. sınıf öğrencilerinin çocuk haklarına ilişkin algıları nasıldır?

2. Uygulama sonrası ilkokul 4. sınıf öğrencilerinin çocuk haklarına ilişkin algıları nasıldır?

3. İlkokul 4. sınıf öğrencilerinin uygulamaya ilişkin görüşleri nelerdir?

\section{YÖNTEM}

\section{Araştırmanın Modeli}

Bu çalışmada ilkokul 4. sınıf öğrencilerinin çocuk haklarına yönelik algılarını oyun ve etkinlikler yoluyla iyileştirmek ve geliştirmek hedeflenmiş, ilgili amaca yönelik olarak çeşitli uygulamalar yapılmıştır. Araştırma bu açıdan nitel araştırma yöntemlerinden biri olan eylem araştırması özelliği taşımaktadır. Eylem araştırması, herhangi bir kurumda çalışan uygulayıcının yalnız kendisi veya bir araştırmacı yardımı ile gerçekleştirdiği, var olan bir sorunu anlamaya ve çözmeye yönelik olarak uygulama yapma, veri toplama ve analiz etme aşamalarını içeren bir araştırma modelidir (Yıldırım \& Şimşek, 2013). Aksoy (2003), eylem 
araştırmasının öne çıkan bazı özelliklerinden bahsetmektedir. Bunlar; uygulamayı iyileştirmenin asıl amaç olması, uygulayıcının araştırma sürecine doğrudan katılması, araştırmanın gerçek ortamda gerçek kişilerle yapılmasıdır. Bu çalışmada da yapılan etkinlikler gerçek bir ortam olan bir ilkokulda, gerçek öğrencilerle yapılmış; araştırmacının da sürece katılması ile çocuk haklarına yönelik algıyı iyileştirmek hedeflenmiştir.

\section{Çalışma Grubu}

Araştırmanın çalışma grubunu 2020-2021 eğitim-öğretim yılında Akdeniz bölgesinde yer alan bir devlet ilkokulunda 4. sınıfta öğrenim görmekte olan 25 ilkokul öğrencisi oluşturmaktadır. Öğrencilerin 14'ü kız, 11'i erkektir. Uygulama sonunda bu öğrencilerden beş gönüllü kişi ile ayrıca görüşme de yapılmıştır. Çalışma grubu olarak birinci araştırmacının görev yaptığı sınıfın seçilmesinden dolayı amaçlı örnekleme yöntemlerinden kolay ulaşılabilirlik dikkate alınmıştır. Kolay ulaşılabilir durum örneklemesi, araştırmacının çalışmasına hız ve pratiklik kazandıran amaçlı örnekleme yöntemlerinden biridir (Yıldırım \& Şimşek, 2013).

\section{Veri Toplama Araçları}

Araştırmada veri toplama aracı olarak zihin haritaları ve araştırmacılar tarafından geliştirilen yapılandırılmış görüşme formu kullanılmıştır. Formun araştırmaya uygunluğu açısından uzman görüşüne başvurularak düzenlemeler yapılmış; uygulamanın öğrencilere ne kattı̆ğ ve onlara nasıl hissettirdiğine dair iki açık uçlu soru sorulmuştur. Zihin haritaları ise, bir kavrama yönelik öğrencilerin zihninde yer edinen bilgi, fikir ve bunlar arasındaki ilişkileri ortaya koymak için iki boyutlu görsel bir tekniktir (Evrekli, İnel \& Balım, 2010). Hazırlanması birçok öğretim yönteminden daha kolay olan zihin haritaları, algıların ortaya çıkarılmasından değerlendirilmesine kadar eğitim-öğretim sürecinde kullanılmaktadır (İnel Ekici, 2015). Bu araştırmada da öğrencilere bir ders saati süresinde zihin haritaları hakkında bilgi verilerek çeşitli örnekler gösterilmiş; uygulama öncesi ve sonrasında çocuk haklarına ilişkin algılarını ortaya koymak amacıyla anahtar kelime olarak zihin haritalarının merkezine "çocuk hakları" kavramını yerleştirerek kendi zihin haritalarını oluşturmaları istenmiştir.

\section{Veri Toplama Süreci}

Araştırmanın başında öğrencilere zihin haritalarının ne olduğuna dair bilgi verilmiş ve örnekler gösterilmiş, daha sonra ise onlardan çocuk haklarına ilişkin bir zihin haritası oluşturmaları istenmiştir. Elde edilen dokümanlar araştırmacılar tarafından incelendiğinde, öğrencilerin çocuk haklarına ilişkin algılarında eksiklikler olduğu tespit edilmiştir. Bu aşamada araştırmacılar tarafından bir eylem planı hazırlanmış ve uzman görüşü alınarak uygulamalar belirlenmiştir. Bu eylem planı ilk araştırmacı tarafından 14 saat boyunca oyun ve etkinlikler yoluyla uygulanmıştır. Uygulamaya ilişkin çalışma planı Tablo 1'de verilmiştir.

\section{Tablo 1.}

Çocuk haklarını öğretmeye yönelik uygulama takvimi ve kazanımlar 


\begin{tabular}{|c|c|c|}
\hline Uygulama Adı & $\begin{array}{c}\text { Uygulama } \\
\text { Süresi }\end{array}$ & Örnek Kazanımlar \\
\hline Yaşama Hakk1 & 2 ders saati & $\begin{array}{l}\text { İnsanın doğuştan gelen temel ve vazgeçilmez hakları olduğunu } \\
\text { bilir. } \\
\text { Haklarına kendi yaşamından örnekler verir. } \\
\text { Kendisini farklı özelliklere sahip diğer bireylerin yerine koyar. }\end{array}$ \\
\hline Sağlık Hakk1 & 2 ders saati & $\begin{array}{l}\text { İnsan sağlı̆̆ ile dengeli beslenmeyi ilişkilendirir. } \\
\text { Tedavi olmanın önemini kavrar. }\end{array}$ \\
\hline Vatandaşlık Hakkı & 2 ders saati & $\begin{array}{l}\text { İnsanların hak ve özgürlükler bakımından eşit olduğunu bilir. } \\
\text { Adaletin veya eşitliğin sağlandığı ve sağlanamadığı durumları } \\
\text { karşlaştırır. }\end{array}$ \\
\hline Eğitim Hakk1 & 2 ders saati & Çocuk olarak sahip olduğu eğitim haklarına örnekler verir. \\
\hline Korunma Hakk1 & 2 ders saati & $\begin{array}{l}\text { Hak ve özgürlüklerini kullanabilen ve kullanamayan çocukların } \\
\text { yaşantılarını karşlaştırır. } \\
\text { İhmal ve istismar hakkında bilgi sahibi olur. }\end{array}$ \\
\hline Katılım Hakkı & 2 ders saati & $\begin{array}{l}\text { Hak ve özgürlüklere saygı gösterir. } \\
\text { Kendi düs̆üncelerini uygun şekilde ifade eder. } \\
\text { Farklı bakış açılarına anlayışa yaklaşmanın önemini kavrar. }\end{array}$ \\
\hline Oyun ve Eğlenme Hakkı & 2 ders saati & $\begin{array}{l}\text { Okul yaşamında gerekli gördüğg̈ eğitsel sosyal etkinlikleri önerir. } \\
\text { Oyun ve fiziki etkinliklerde iş birliği yapar. } \\
\text { Oyun ve fiziki etkinliklerde adil oyun anlayışı sergiler. }\end{array}$ \\
\hline
\end{tabular}

Oyun ve etkinlikler yoluyla yapılan uygulama sonrasında öğrencilerden yeniden çocuk haklarına ilişkin zihin haritalarını oluşturmaları istenmiştir. Elde edilen dokümanlar toplandıktan sonra ise gönüllü beş öğrenci ile uygulamaya dair görüşmeler yapılmıştır. Toplanan veriler betimsel analiz ile analiz edilmiştir.

\section{Verilerin Analizi}

Uygulama öncesinde ve sonrasında toplanan zihin haritalarına ilişkin veriler doküman incelemesi yoluyla çözümlenmiş, transkript edilen görüşmelerle birlikte betimsel analiz kullanılarak analiz edilmiştir. Betimsel analiz, araştırmacılar tarafından önceden belirlenen birtakım temalara göre verilerin yorumlanması işlemidir (Yıldırım \& Şimşek, 2013). Bu çalışmadaki temalar ise yaşama hakkı, sağlık hakkı, vatandaşlık hakkı, eğitim hakkı, korunma hakkı, katılım hakkı, oyun/eğlenme hakkı ve diğer olarak belirlenmiştir. Elde edilen veriler iki ayrı araştırmacı tarafından analiz edilmiş ve Miles ve Huberman'ın (1994) güvenirlik formülüne göre \%89 oranında görüş birliğine varılmıştır. Ayrıca görüşme verilerinin geçerliğini sağlamak amacıyla katılımcı teyidi yapılarak öğrencilerden ifadelerini doğrulamaları istenmiştir.

\section{BULGULAR}

\section{Birinci Alt Probleme İlişkin Bulgular}

Araştırmanın birinci alt problemi "Uygulama öncesi ilkokul 4.sınıf öğrencilerinin çocuk haklarına ilişkin algıları nasıldır?" şeklindedir. Bu alt probleme yönelik bulgular Tablo 2'de verilmiştir.

\section{Tablo 2.}

Uygulama öncesi ilkokul 4. sını öğrencilerinin çocuk haklarına ilişkin algıları 


\begin{tabular}{|c|c|c|}
\hline Temalar & Kodlar & $f$ \\
\hline \multirow{6}{*}{ Yaşama Hakkı } & Barınma & 8 \\
\hline & Beslenme & 7 \\
\hline & Sevme ve sevilme & 6 \\
\hline & Aileye sahip olma & 5 \\
\hline & Dinlenme & 1 \\
\hline & Toplam & 27 \\
\hline \multirow{3}{*}{ Sağlık Hakkı } & Tedavi olma & 4 \\
\hline & İlaç alma & 1 \\
\hline & Toplam & 5 \\
\hline \multirow{2}{*}{ Vatandaşlık Hakkı } & Özgürlük & 4 \\
\hline & Toplam & 4 \\
\hline \multirow{7}{*}{ Eğitim Hakkı } & Eğitim alma & 9 \\
\hline & Okula gitme & 8 \\
\hline & Ders görme & 7 \\
\hline & Ödev yapma & 6 \\
\hline & Öğrenci olma & 4 \\
\hline & Bilgi edinme & 2 \\
\hline & Toplam & 36 \\
\hline \multirow{2}{*}{ Korunma Hakkı } & Kişi dokunulmazlığı & 5 \\
\hline & Toplam & 5 \\
\hline \multirow{3}{*}{ Katılım Hakkı } & Düşünce ve ifade özgürlüğü & 6 \\
\hline & Sayg1 görme & 2 \\
\hline & Toplam & 8 \\
\hline \multirow{7}{*}{ Oyun ve Eğlenme Hakkı } & Oyun oynama & 13 \\
\hline & Eğlenme & 9 \\
\hline & Parka gitme & 3 \\
\hline & Saklambaç oynama & 2 \\
\hline & Gezme & 1 \\
\hline & Spor yapma & 1 \\
\hline & Toplam & 29 \\
\hline \multirow{4}{*}{ Diğer } & Arkadaşlık kurma & 5 \\
\hline & Mutlu olma & 5 \\
\hline & Yardımlaşma & 1 \\
\hline & Toplam & 11 \\
\hline
\end{tabular}

Tablo 2 incelendiğinde öğrencilerin sırası ile en çok eğitim hakkı ( $f=36)$, oyun/eğlenme hakkı $(\mathrm{f}=29)$ ve yaşama hakkına ( $\mathrm{f}=27)$ yönelik cevapları olduğu görülmektedir. En az sayıda ise vatandaşlık hakkı $(\mathrm{f}=4)$, sağlık hakkı $(\mathrm{f}=5)$ ve korunma hakkı $(\mathrm{f}=5)$ temalarına değinilmiştir. Özellikle korunma hakkı teması kapsamında yer alan "başkalarının haklarını koruyabilme", "İhmal ve istismardan korunabilme", "şiddetten korunma" ve "şiddet uygulamama" kodlarına ilişkin hiçbir öğrenci görüş bildirmemiştir. Öğrencilerin uygulama öncesi zihin haritalarından örnekler Şekil 1 ve Şekil 2'de verilmiştir. 


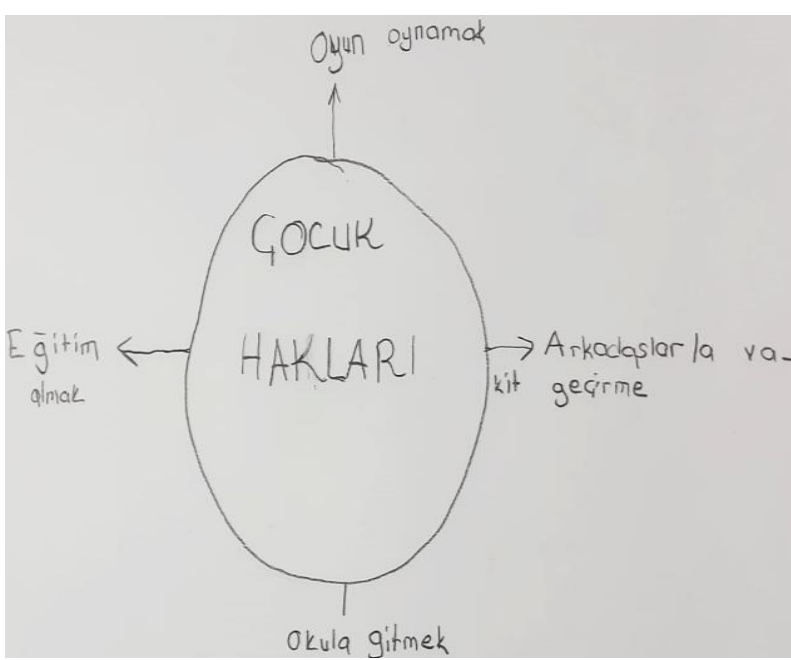

Resim 1. Uygulama öncesi zihin haritası örneği 1

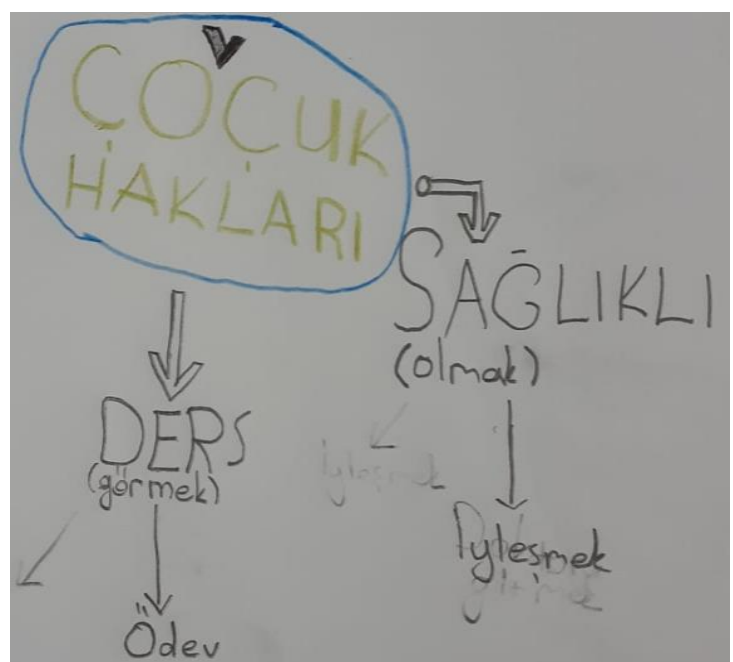

Resim 2. Uygulama öncesi zihin haritası örneği 2

\section{İkinci Alt Probleme İlişkin Bulgular}

Araştırmanın ikinci alt problemi “Uygulama sonrası ilkokul 4.sınıf öğrencilerinin çocuk haklarına ilişkin algıları nasıldır?" şeklindedir. Bu alt probleme yönelik bulgular Tablo 3'te verilmiştir.

\section{Tablo 3.}

Uygulama sonrası ilkokul 4. sını öğrencilerinin çocuk haklarına ilişkin algıları

\begin{tabular}{llc}
\hline Temalar & Kodlar & $f$ \\
\hline & Sevme ve sevilme & 19 \\
& Barınma & 17 \\
Beslenme & 16 \\
Yaşama Hakkı & Dinlenme & 7 \\
& Giyinme & 5 \\
& Uyuma & 4 \\
& Aileye sahip olma & 3 \\
& Birey olma & 2 \\
& Toplam & $\mathbf{7 3}$ \\
\hline \multirow{5}{*}{ Sağlık Hakkı } & Tedavi olma & 14 \\
& Bakım & 1 \\
& İlaç alma & 1 \\
& Toplam & $\mathbf{1 6}$ \\
\hline & Kimlik sahibi olma & 11 \\
Vatandaşlık Hakkı sahibi olma & 9 \\
& İir ülke vatandaşı olma & 8 \\
& Özgürlük & 7 \\
& Eşit olma & 6 \\
& Demokrasi & 1 \\
& Toplam & $\mathbf{4 2}$ \\
\hline
\end{tabular}




\begin{tabular}{|c|c|c|}
\hline \multirow{8}{*}{ Eğitim Hakkı } & Eğitim alma & 12 \\
\hline & Okula gitme & 7 \\
\hline & Yaz1 yazma & 5 \\
\hline & Bilgi edinme & 4 \\
\hline & Öğrenci olma & 2 \\
\hline & Ödev yapma & 2 \\
\hline & Ders Görme & 2 \\
\hline & Toplam & 34 \\
\hline \multirow{6}{*}{ Korunma Hakkı } & Şiddetten korunma & 18 \\
\hline & İhmal ve işmardan korunma & 18 \\
\hline & Kişi dokunulmazlığı & 10 \\
\hline & Şiddet farkındalığ & 3 \\
\hline & Başkalarının haklarını koruma & 2 \\
\hline & Toplam & 51 \\
\hline \multirow{7}{*}{ Katılım Hakkı } & Düşünce ve ifade özgürlüğü & 17 \\
\hline & Sayg1 görme & 5 \\
\hline & Cevap verme & 4 \\
\hline & Konuşma & 3 \\
\hline & Fikirlere sayg 1 duyma & 2 \\
\hline & Hakkını arayabilme & 1 \\
\hline & Toplam & 32 \\
\hline \multirow{7}{*}{ Oyun ve Eğlenme Hakkı } & Oyun oynama & 12 \\
\hline & Parka gitme & 5 \\
\hline & Eğlenme & 4 \\
\hline & Saklambaç oynama & 2 \\
\hline & Gezme & 2 \\
\hline & Spor yapma & 1 \\
\hline & Toplam & 26 \\
\hline \multirow{9}{*}{ Diğer } & İş yapmama & 5 \\
\hline & Engellilere saygilı olma & 4 \\
\hline & Mutlu olma & 3 \\
\hline & Merak etme & 3 \\
\hline & Arkadaşlık kurma & 2 \\
\hline & Yardımlaşma & 1 \\
\hline & Koşma & 1 \\
\hline & Empati yapma & 1 \\
\hline & Toplam & 20 \\
\hline
\end{tabular}

Tablo 3'e bakıldığında uygulama sonrasında öğrencilerin sırasıyla en çok yaşama hakkı (f=73), korunma hakkı ( $\mathrm{f}=51)$ ve vatandaşlık hakkına ( $\mathrm{f}=42)$ ilişkin görüş bildirdiği görülmektedir. Uygulama öncesinde neredeyse hiç değinilmeyen korunma hakkı ile vatandaşlık hakkına uygulama sonrasında birçok çocuğun değindiği görülmektedir. Öğrencilerin uygulama öncesi zihin haritalarından örnekler Şekil 3 ve Şekil 4'te verilmiştir. 


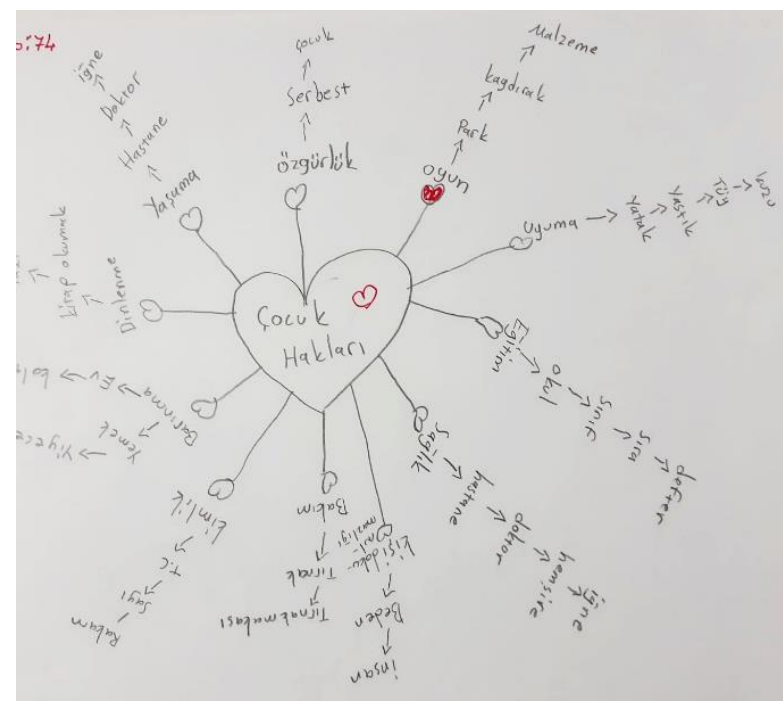

Resim 3. Uygulama sonrası zihin haritası örneği 1

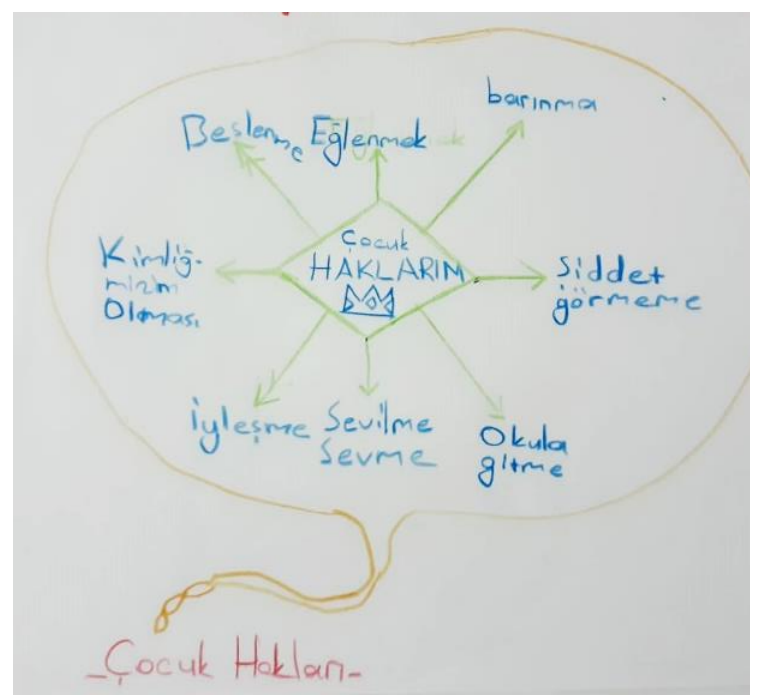

Resim 4. Uygulama sonrası zihin haritası örneği 2

\section{Üçüncü Alt Probleme İlişkin Bulgular}

Araştırmanın üçüncü alt problemi "İlkokul 4.sınıf öğrencilerinin uygulamaya ilişkin görüşleri nelerdir?" şeklindedir. Öğrenciler oyun ve etkinliklerle yapılan uygulama sonrasında haklarına dair bilgi sahibi olarak günlük hayatlarına bunu yansıttıklarını, öğrendiklerini çevrelerindeki insanlara (ailelerine, arkadaşlarına, komşularına) anlattıklarını, kendi haklarını korumanın yanı sıra başkalarının haklarını da koruyup gözettiklerini, onların da haklarına sayg1 gösterdiklerini ve tüm uygulama süreci boyunca mutlu ve heyecanlı hissederek çok eğlendiklerini belirtmişlerdir. Bu konuya ilişkin görüşler aşağıda verilmiştir.

"Çalışmalar yaptığımız için o gün eğlendim. Çocukken haklarımızı bilmemiz gerekiyor. Haklarımızı bilmezsek ileride haklarımızı kullanmayız. Mesela barınma, eğitim hakkımızı koruyamayız. Bütün haklarımızı bilirsek onları koruyabiliriz ve kullanabiliriz. Haklarm kullanabilen biri mutlu olur. Haklarm kullanmayan biri mutsuz olur. Aileme de çocuk haklarını öğrendiğimizi söyledim, yaptığımız çalışmaları anlattım." Ö3

"Bilmediğim çocuk hakları varmış bunları öğrendim. Çocuk haklarını bilirsek haklarımızı koruyabiliriz. Bir olay olduğunda haklarımızı bildiğimiz için bir şeyler yapabiliriz. Sorunları çözebiliriz. Mutluluk ve heyecan hissettim. Mutlu oldum çünkü bir şeyler öğreniyordum ve oyun oynuyordum ayn zamanda. Çok güzel geçti ve bir şeyler öğrendik. Mesela öğrenmeden önce başkası bana dokunduğunda istemiyordum ama artık öğrendim ki dokunulmamak benim hakkım." Ö4

"O gün birbirimizin haklarını çalmamayı yani engellememeyi öğrendim. Bazı insanların haklarını tam kullanmadıklarını öğrendim. Yararlı oldu ve eğlendim. Ĕğer çocuk haklarını öğrenmezsek ileride çocuk haklarını koruyamayabiliriz ve haklarımız çalınabilir. O gün üzüldüm çünkü insanların ve çocukların haklarını kullanamaması gerçekten üzücü. Aynı zamanda sevindim çünkü bu uygulama sayesinde ben bütün haklarımı biliyorum artık." Ö5 
"Başka haklarım olduğunu öğrendim. Haklarımı daha iyi kullanabileceğimi öğrendim. Mesela oyun oynamanın bizim hakkımız olduğu beni şaşırttı. Yeni öğrendiğim haklarımı aileme anlattım. Oyunları oynarken çok mutlu oldum." Ö2

"Sadece kendi haklarımızı değil başkalarının hakların da korumalıyız. Büyüdüğ̈̈̈müzde de çocukların haklarını koruyabileceğimizi gördüm. Derste oyun oynamak ve yeni şeyler öğrenmek mutlu hissettirdi. O günkü dersten sonra oyun oynarken benim oyuncaklarımı kendilerinin olmasını isteyenlere onlarm benim oldukların söylüyorum ve onlarla sadece paylaşarak oynayabileceğimizi söylüyorum." Ö1

\section{SONUÇ VE TARTIŞMA}

$\mathrm{Bu}$ araştırmanın amacı çocuk haklarına ilişkin algılarında eksiklikler tespit edilen ilkokul 4. sınıf öğrencilerinin çocuk hakları algılarını eylem araştırması çerçevesinde geliştirmek ve iyileştirmektir. Bu kapsamda bir eylem planı hazırlanmış ve öğrencilere sürece dair bilgi verilmiştir. Toplam 14 saat süren uygulama sonrasında öğrencilerin çocuk haklarına ilişkin algıları zihin haritaları aracılığı ile toplanmış ve öğrencilerin uygulama hakkındaki görüşleri alınmıştır. Yapılan analizler sonucu elde edilen sonuçlar aşağıda verilmiştir.

Uygulama öncesinde öğrencilerin çocuk haklarına ilişkin algılarında eksiklikler olduğu belirlenmiştir. Buna göre 4. sınıf öğrencilerinin zihin haritalarında sırasıyla en çok eğitim hakkı $(\mathrm{f}=36)$, oyun/eğlenme hakkı $(\mathrm{f}=29)$ ve yaşama hakkına $(\mathrm{f}=27)$ yönelik cevapları olduğu görülmektedir. En az sayıda ise vatandaşlık hakkı $(\mathrm{f}=4)$, sağlık hakkı $(\mathrm{f}=5)$ ve korunma hakkı $(\mathrm{f}=5)$ temalarına değinilmiştir. Gültekin, Gürdoğan Nayır ve Balbağ (2016), araştırmalarına dahil olan tüm ilkokul 4. sınıf öğrencilerinin oyun ve eğlenme hakkı, yaşam hakkı ve eğitim hakkına vurgu yaptıklarını ortaya koymuştur. Benzer şekilde Ersoy (2011) de ilköğretim öğrencileri ile yaptığı araştırmada, öğrencilerin çocuk haklarına ilişkin algılarının en fazla eğitim hakkı ile oyun ve eğlenme hakkına yönelik olduğu; korunma hakları ile katılım haklarına ilişkin bilgi düzeylerinin yeterli seviyede olmadığı sonucuna ulaşmıştır. Uysal Bayrak, Gök, Yörük ve Kaya'nın (2019) okul öncesi dönem çocuklarının çocuk hakları algılarını inceledikleri çalışmada, çocukların en çok oyun hakkına yönelik çizimler yaptıkları görülmektedir. Bayram, Bulduk ve Çavuş (2017) ise okul öncesi dönem çocuklarının çocuk haklarına ilişkin resimlerinde katılım hakkına hiç yer vermediklerini ortaya koymuştur. Bu sonuçlar, araştırmanın sonuçları ile örtüşmektedir.

Uygulama sonrasında ise öğrencilerin sırasıyla en çok yaşama hakkı (f=73), korunma hakkı $(\mathrm{f}=51)$ ve vatandaşlık hakkına $(\mathrm{f}=42)$ ilişkin görüş bildirdiği görülmektedir. Uygulama öncesinde neredeyse hiç değinilmeyen korunma hakkı ile vatandaşlık hakkına uygulama sonrasında birçok çocuğun değindiği görülmektedir. Ayrıca tüm temaların frekanslarında büyük oranda artış olduğu, öğrencilerin uygulama sonrasında çocuk haklarına ilişkin bilgi ve farkındalık kazandıkları söylenebilir. Covell ve Howe (1999) verdikleri çocuk hakları eğitimi sonunda öğrencilerin korunma, eğitim, sağlık ve katılım haklarına ilişkin bilgi düzeylerinin arttığı sonucuna ulaşmıştır. Washington (2010) aile katılımlı çocuk hakları eğitimi sonunda 
öğrencilerin çocuk haklarına yönelik farkındalıklarının arttığını tespit etmiştir. Torun (2011) oyunlarla zenginleştirilmiş çocuk hakları eğitimi ile öğrencilerin çocuk haklarına ilişkin tutumlarının ve akademik başarılarının arttığını; Çarıkçı (2019) ise ilkokul 4. sınıf öğrencileri için gerçekleştirdiği çocuk hakları eğitimi programı ile, öğrencilerin çocuk haklarına yönelik tutum ve farkındalıklarının arttı̆̆ını ortaya koymuştur. Şenol ve Akyol'un (2017) araştırmasında çocuk hakları etkinliklerinden sonra okul öncesi dönem çocuklarının bilgi ve farkındalıklarının yaşama, oyun, beslenme, barınma, sağlık, katılım ve korunma hakları kategorilerinde arttığ1 görülmüştür. Bu noktada literatürde yapılan çalışmalar da dikkate alındığında çocuk hakları eğitimlerinin, öğrencilere bilgi, tutum ve farkındalık kazandırmada etkili bir yol olduğu söylenebilir.

Öğrencilerin uygulamaya yönelik görüşlerine bakıldığında ise tamamının olumlu olduğu görülmektedir. Öğrenciler uygulama sonrasında bilgi düzeylerinin arttığını, kendi haklarına yönelik farkındalıklarını başkalarının da haklara sahip olduğu bilinci ile geliştirdiklerini, uygulamayı aile ve arkadaşları ile paylaştıklarını belirtmişlerdir. Ayrıca uygulama boyunca çok eğlendiklerini ve mutlu olduklarını da ifade etmişlerdir. Torun (2011) da oyunlarla zenginleştirdiği çocuk hakları eğitimi sonunda çocukların mutlu hissettikleri ve çok eğlendikleri sonucuna ulaşmıştır. Bu durum, çocukların çocuk hakları eğitimine ve eğitimi gerçekleştiren öğretmene olan tutumlarını da olumlu yönde etkilemiştir. Çarıkçı (2019) ise gerçekleştirdiği çalışma kapsamında, çocuk hakları eğitimi programının ilkokul 4. sınıf öğrencileri üzerinde olumlu etkileri olduğunu ortaya koymuştur. Öğrenciler genel olarak süreç boyunca eğlendiklerini ve mutlu hissettiklerini belirtmiştir. Özellikle okul öncesi ve ilkokul dönemindeki öğrenciler için oyunlarla zenginleştirilmiş ders planlarının öğrencilerde olumlu duygulara sebep olduğu söylenebilir.

Çalışma sonuçları doğrultusunda, farklı sınıf düzeylerindeki öğrencilerin çocuk haklarına ilişkin algılarının ne düzeyde olduğunun belirlenmesine ilişkin çalışmalar yapılmalı ve tespit edilen eksiklikler olması durumunda çocuk hakları eğitimleri hazırlanmalıdır. Bu noktada sınıf öğretmeni ve öğretmen adaylarının da çocuk haklarına ilişkin bilgi düzeyleri önem kazanmaktadır (Şeren \& Özkara, 2019). Çocuk haklarına ilişkin farkındalık oluşturmanın yalnızca çocuklar ile sağlanamayacağı unutulmamalı; bunun yanında öğretmen, öğretmen adayları ve velilerin eğitimlerine, ders ve çocuk kitaplarına, öğretim programlarına da çocuk haklarının etkili bir şekilde yansımasının gerçekleştirilmesi yönünde adımlar atılmalıdır.

\section{KAYNAKÇA}

Aksoy, N. (2003). Eylem araştırması: Eğitimsel uygulamaları iyileştirme ve değiştirmede kullanılacak bir yöntem. Kuram ve Uygulamada Eğitim Yönetimi, 36, 474-489.

Akyüz, E. (2000). Çocuğun haklarının ve güvenliğinin korunması. Ankara: Milli Eğitim.

Ay Zöğ, D. (2008). Öğrencilerin çocuk haklarını algılama düzeyleri ile akademik başarıları arasındaki ilişki (İstanbul ili Beyoğlu ilçesi örneği). (Yayımlanmamış Yüksek Lisans Tezi), Beykent Üniversitesi Sosyal Bilimler Enstitüsü, İstanbul. 
Bayram, Z., Bulduk, Z. \& Çavuş, Z. S. (2017). “Çocuk Hakları” temalı çocuk resimleri üzerine bir inceleme. Ö. Pınarcık ve M. Özözen Danacı (Ed.), Uluslararası Çocuk Hakları Kongresi Tam Metin Kitabı içinde (s. 240- 247). Ankara: Eğiten Kitap.

Beeckman, K. (2004). Measuring the implementation of the right to education: Educational versus human rights indicators. The International Journal of Children's Rights, 12, 71-84.

Covell, K. \& Howe, R. B. (1999). The impact of children's rights education: A Canadian study. International Journal of Children's Rights, 7, 171-183.

Çarıkçı, S. (2019). Çocuk hakları eğitimi programının ilkokul 4. sınıf öğrencilerinin çocuk hakları tutum ve farkındalıklarına etkisi. (Yayımlanmamış Doktora Tezi), Marmara Üniversitesi Eğitim Bilimleri Enstitüsü, İstanbul.

Durgut, A. (2014). 2005 Sosyal bilgiler dersi öğretim programlarının çocuk hakları açısından incelenmesi. (Yayımlanmamış Yüksek Lisans Tezi), Dumlupınar Üniversitesi Eğitim Bilimleri Enstitüsü, Kütahya.

Erbay, E. (2012). Türkiye'de çocuk haklarını tanıtma, yaygınlaştırma ve izlemeye yönelik uygulamaların eleştirel analizi ve bir model önerisi. Toplum ve Sosyal Hizmet Dergisi, 23(2), 47-74.

Ersoy, A. F. (2011). İlköğretim öğrencilerinin çocuk haklarına ilişkin algıları. İlköğretim Online, 10(1), 20-39.

Evrekli, E., İnel, D. \& Balım, A. G. (2010). Development of a scoring system to assess mind maps. Procedia- Social and Behavioral Sciences, 2(2), 2330-2334.

Gültekin, Gürdoğan Bayır ve Balbağ (2016). Haklarımız var: Çocukların gözünden çocuk hakları. Adıyaman Üniversitesi Sosyal Bilimler Enstitüsü Dergisi, 8(24), 971-1006.

Hareket, E. (2015). Çocuk meclisi uygulamalarının bazı değişkenlere göre çocuk haklarına ilişkin algı gelişimine etkisi. (Yayımlanmamış Yüksek Lisans Tezi), Ondokuz Mayıs Üniversitesi Eğitim Bilimleri Enstitüsü, Samsun.

Izgar, G. (2017). İnsan hakları, yurttaşlık ve demokrasi ders kitabının yapılandırmacı yaklaşım açısından analizi. İlköğretim Online, 16(2),584-600.

İnel Ekici, D. (2015). Fen öğretmeni adaylarının bilime ilişkin algılarının zihin haritaları yoluyla belirlenmesi. Mehmet Akif Ersoy Üniversitesi Eğitim Fakültesi Dergisi, 34, 132151.

Karaman Kepenekçi, Y. (2000). Insan hakları eğitimi. Ankara: Anı Yayıncılık.

Kaymak Özmen, S., Öcal, T. \& Özmen, A. (2014). The effect of children's rights training on primary school students' utilization and knowledge level about children's rights' education. International Journal of Primary, Elementary and Early Years Education, 4(2), 138-153. 
Miles, A. M., \& Huberman, M. B. (1994). Qualitative data analysis: An expanded sourcebook. Thousand Oaks CA: Sage.

Milli Eğitim Bakanlığı, (2018). Sosyal Bilgiler Dersi Öğretim Programı (Illkokul ve Ortaokul 4, 5,6 ve 7. Siniflar). https://mufredat.meb.gov.tr/Dosyalar/201812103847686SOSYAL $\% 20$ B $\%$ C4\%B0LG\%C4\%B0LER\%20\%C3\%96\%C4\%9ERET\%C4\%B0M\%20PR OGRAMI\%20.pdf adresinden 07.09.2021 tarihinde erişilmiştir.

Neslitürk, S. \& Ersoy, A. F. (2007). Okul öncesi öğretmen adaylarının çocuk haklarının öğretimine ilişkin görüşleri. Eğitimde Kuram ve Uygulama Dergisi, 3(2), 245-257.

Özdemir Doğan, G. (2017). Çocuk hakları eğitiminde uzman sinıf öğretmenlerinin perspektifinden etkili çocuk hakları eğitimi: Anlayışlar ve uygulamalar. (Yayımlanmamış Yüksek Lisans Tezi), Gaziantep Üniversitesi Eğitim Bilimleri Enstitüsü, Gaziantep.

Özdemir Uluç, F. (2008). İlköğretim programlarında çocuk hakları. (Yayımlanmamış Doktora Tezi), Ankara Üniversitesi Sosyal Bilimler Enstitüsü, Ankara.

Şenol, F. B. \& Akyol, T. (2017). Okul öncesi dönem çocuklarının çocuk haklarına yönelik farkındalıklarını geliştirmeye yönelik bir uygulama örneği (Pilot Çalışma). Ö. Pınarcık ve M. Özözen Danacı (Ed.), Uluslararası Çocuk Hakları Kongresi Tam Metin Kitabı içinde (s. 299-312). Ankara: Eğiten Kitap.

Şeren, N. \& Özkara, Y. (2019). Sınıf öğretmeni adaylarının ödüllü çocuk kitaplarını çocuk hakları bağlamında değerlendirmesi. Z. Kabasakal (Ed.), Eğitim ve Erken Çocukluk Dönemi içinde (s. 35-52). Ankara: İksad Yayınevi.

Torun, F. (2011). Çocuk hakları öğretiminde oyun yönteminin başarıya, kalıcılığa ve tutuma etkisi. (Yayımlanmamış Yüksek Lisans Tezi), Adıyaman Üniversitesi Sosyal Bilimler Enstitüsü, Adıyaman.

Turupcu, A. \& Gültekin Akduman, G. (2015). Okul öncesi eğitim ve çocuk hakları. G. Uyanık Balat (Ed.). Okul öncesi eğitime giriş içinde (s.235-252). Ankara: Nobel Akademi Yayıncilık.

Uçuş, Ş. (2014). Çocuk hakları eğitimi programının hazırlanması ve değerlendirilmesi: Uygulama öğretmeninin ve katılımcıların görüşleri. International Journal of New Trends in Arts, Sports and Science Education, 3(2), 1-21.

Uysal Bayrak, H., Gök, H. N., Yörük, E. \& Kaya, E. (2020). Okul Öncesi Dönemdeki Çocukların Gözünden Çocuk Hakları. Uluslararası Erken Çocukluk Eğitimi Çalışmaları Dergisi, 4(2), 63-73.

Washington, F. (2010). 5-6 yaş grubu çocuklarına uygulanan aile katılımlı çocuk hakları eğitimi programının etkililiğinin incelenmesi. (Yayımlanmamış Yüksek Lisans Tezi), Marmara Üniversitesi Eğitim Bilimleri Enstitüsü, İstanbul.

Yıldırım, A., \& Şimşek, H. (2013). Sosyal bilimlerde nitel araştırma yöntemleri (9. Baskı). Ankara: Seçkin Yayıncılık. 


\section{ÖRNEK UYGULAMA PLANI}

\section{BÖLÜM I}

\begin{tabular}{|c|c|c|}
\hline \multicolumn{2}{|l|}{ Sinif } & 4.sinif \\
\hline \multicolumn{2}{|l|}{ Süre } & 30 dakika \\
\hline \multicolumn{2}{|l|}{ Ders } & İnsan Hakları, Yurttaşlık ve Demokrasi \\
\hline \multicolumn{2}{|l|}{ Ünite } & İnsan Olmak \\
\hline \multicolumn{3}{|l|}{ BÖLÜM II } \\
\hline \multicolumn{2}{|c|}{$\begin{array}{l}\text { Öğrenci } \\
\text { Kazanımları/Hedef } \\
\text { Davranışlar }\end{array}$} & $\begin{array}{l}\text { Y.4.1.2. İnsanın doğuştan gelen temel ve vazgeçilmez hakları olduğunu } \\
\text { bilir. } \\
\text { Y.4.2.6. Hak ve özgürlüklere saygı gösterir. }\end{array}$ \\
\hline \multicolumn{2}{|c|}{$\begin{array}{l}\text { Öğrenme-Öğretme Strateji, } \\
\text { Yöntem ve Teknikleri }\end{array}$} & Soru cevap tekniği, eğitsel oyunlar \\
\hline \multicolumn{2}{|c|}{$\begin{array}{l}\text { Kullanılan Eğitim } \\
\text { Teknolojileri, Araç- } \\
\text { Gereçler }\end{array}$} & Renkli balonlar, bilgisayar \\
\hline \multirow{3}{*}{$\begin{array}{l}\text { Öğretme- } \\
\text { Öğrenme } \\
\text { Etkinlikleri }\end{array}$} & $\begin{array}{l}\text { Dikkat } \\
\text { Çekme }\end{array}$ & $\begin{array}{l}\text { Öğretmen elinde renkli balonlarla içeri girer. Öğrencilere her balona bir } \\
\text { öğrencinin ismini yazacağını ve o balonu o öğrenciye vereceğini söyler. } \\
\text { Öğretmen, balonların öğrencilere gizli bir mesajı olduğunu belirtir. }\end{array}$ \\
\hline & Güdüleme & $\begin{array}{l}\text { Öğretmen öğrencilere balonlarla bir oyun oynayacaklarını ve eğer } \\
\text { yapacakları oyuna katılım sağlarlarsa balonların onlara vermek istediği } \\
\text { mesajı balonlar kendilerine söylemeden öğrenebileceklerini söyler. }\end{array}$ \\
\hline & $\begin{array}{l}\text { Derse } \\
\text { Geçiş }\end{array}$ & $\begin{array}{l}\text { Öğretmen her öğrenciye isminin yazılı olduğu balonu verir. Öğrencilere } \\
\text { bilgisayardan müzik açacağını söyler ve müzik açıldığında herkesin } \\
\text { kendi balonunu havaya atıp balonuyla dans etmesini ister. Müziği } \\
\text { durdurduğunda ise herkesin kendi balonunu bulmasını ister. Daha } \\
\text { sonra öğrencilere "Kendi balonunuzu bulabildiniz mi?", "Sizce neden } \\
\text { kendi balonunuzu bulamadınız?" sorularını sorar. Alınan cevaplar } \\
\text { sonrasında öğrencilere tekrar müziği açıp balonlarla dans edeceklerini } \\
\text { ancak müzik kapandığı zaman bu sefer kendi balonlarını bulmaya } \\
\text { çalışmamalarını, ellerine ilk gelen balonu yakalayıp tutmalarını söyler. } \\
\text { Müzik kapandığı zaman her öğrencinin elindeki balon üzerinde ismi } \\
\text { yazılı olan kişiye balonunu vermesini belirtir. }\end{array}$ \\
\hline
\end{tabular}

\section{BÖLÜM III}

\begin{tabular}{|l|l|}
\hline Ölçme-Değerlendirme & $\begin{array}{l}\text { Öğretmen öğrencilere her iki uygulama arasındaki farkları sorar. } \\
\text { Balonların onlara vermek istediği mesajın ne olabileceğini sorar. Bütün } \\
\text { uygulama sonrasında öğrencilere balonların her birinin onların haklarını } \\
\text { temsil ettiğini belirtir. Öğrenciler kendi haklarının yanı sıra diğer insanların } \\
\text { da hakları olduğunu tartı̧ır. Her insanın yaşama, sağlık, vatandaşlık, } \\
\text { eğitim, korunma, katılım, oyun ve eğlenme hakkının olduğu vurgulanır. } \\
\text { Eğer öğrenciler haklarını öğrenirlerse hem kendi haklarını hem de } \\
\text { arkadaşlarının haklarını koruyabileceklerine ilişkin çıkarımlar yapılır. }\end{array}$ \\
\hline $\begin{array}{l}\text { Uygulamanın Diğer } \\
\text { Derslerle İlişkisi }\end{array}$ & Beden Eğitimi ve Oyun- BO.4.1.1.4. Özgün, danslar yapar. \\
\hline
\end{tabular}

\section{BÖLÜM IV}

Genel Özet

Öğretmen balonlar yardımıyla öğrencilere hem kendi haklarının hem de başkalarının hakları olduğunu kazandırır. 